\title{
The Evaluation of Skin Prick Test Results in Sirnak
}

\section{City}

\section{Şırnak Ilinde Yapılan Prik Test Sonuçlarının Değerlendirilmesi}

\author{
Suat Konuk ${ }^{1}$ ve Hikmet Çoban ${ }^{2^{*}}$ \\ ${ }^{1}$ Private Clinic, Rose Business Center in Duzce, Turkey \\ ${ }^{2}$ Sakarya Training And Research Hospital Chest Diseases, Sakarya, Turkey
}

\begin{abstract}
Objective: Skin prick test is an easy, cheap, safe, fast, and frequently used test to identify allergic diseases. Several factors such as genetic tendency, climate, humidity, vegetation, and altitude effect development of allergies.

Our goal was to determine the allergic susceptibility of allergic patients in Sirnak City.

Material and Methods: Medical files of 240 patients who referred to our Chest Disease policlinics in Sirnak State Hospital between February 2011 and June 2011 with respiratory complaints suggestive of allergic diseases such as asthma and allergic rhinitis, were retrospectively reviewed. Skin prick test results were evaluated according to age and gender.
\end{abstract}

Results: 240 patients were included in the study, 127 $(52.9 \%)$ were male and $113(47.1 \%)$ were female. The most common allergic reaction was against grasses, observed in 41 patients $(17.1 \%)$. The other common allergic reactions were against grains, in 28 patients $(11.6 \%) ;$ D. Farinea in 17 patients $(7.1 \%)$; D Pteronyssinus in 11 patients $(4.6 \%)$; grass $\operatorname{mix}$ in 9 patients $(3.7 \%)$.

Conclusions: Reactions were most commonly observed in the age group of 10-19 years. Asthma and allergic rhinitis patients in Sirnak City should particularly be careful against grasses, grains, and house dust mites.

Keywords: Allergy, asthma, allergic rhinitis, skin prick test, Sirnak

\section{Introduction}

Immunoglobulin $\mathrm{E}$ ( $\mathrm{IgE}$ ) is the most relevant factor in allergies induced by environmental, nutritional or drug-related agents. The skin prick test is the fastest, the most sensitive and costeffective method to identify IgE-related allergies (1). Sudden hypersensitivity reactions against

\section{ÖZET}

Amaç: Deri prik testi, alerjik hastalıkların belirlenmesinde kullanılan kolay, ucuz, güvenli, çabuk sonuç veren ve sık kullanılan bir testtir. Alerji gelişmesini etkileyen genetik yatkınlık, iklim, nem, bitki örtüsü, rakım gibi faktörler vardır.

Şırnak ilindeki allerjik hastaların alerji duyarlılığının belirlenmesidir.

Gereç ve Yöntem: Şubat 2011 ile Haziran 2011 arasında Şırnak Devlet Hastanesi'nde Gögüs Hastalıkları polikliniklerine astım ve alerjik rinit gibi solunumsal alerjik hastalık şikayeti ile başvuran 240 hastanın dosyaları retrospektif olarak incelendi. Deri prik test sonuçları yaşa ve cinsiyete göre değerlendirildi.

Bulgular: Çalışmaya dahil edilen 240 hastanın 127'si (\%52.9) erkek, 113'ü (\%47.1) ise kadındı. En s1k reaksiyon 41 hasta (17.1) ile çimenlere karşı saptanmıştır. Diğer s1k görülen reaksiyonlar ise 28 hasta ile (\%11.6) tahillara, 17 hasta ile (\%7.1) D. Farinea' ya, 11 hasta ile (\%4.6) D. Pteronyssinus'e ve 9 hasta ile (\%3.7) ot karışımına karşı saptanmıştır. Reaksiyonlar en sık 10-19 yaş grubunda saptandi.

Sonuç: Şırnak'da astım ve allerjik rinit hastaları özellikle çimen, tahıl ve ev tozu akarları alerjenlerine karşı dikkatli olmalidir.

Anahtar Kelimeler: Alerji, astım, allerjik rinit deri prik test, Şırnak

allergens are relatively common among children with asthma or rhinitis, and among young adults. Susceptibility to major household allergens (such as dust mites, cats, dogs or cockroaches) is considered to be the most significant risk factor for the development of asthma (2,3). Allergies are a series of pathological conditions that develop in genetically susceptible individuals due to 
sensitization after exposure to different allergens. Contrary to the previous use of the Latin term "atopy", this terms is now used to define the group of patients having one or more of the conditions such as asthma, allergic rhinoconjunctivitis and contact dermatitis, accompanied by an increase in inherited $\operatorname{IgE}$ antibodies and a medical or family history of atopy (4).

There is a complex interaction between allergic diseases and genetic factors. The high probability of observing allergic compatibility between maternal twins and the increased frequency of atopy among individuals having at least one parent with atopy demonstrate the impact of genetic factors (5). Allergic diseases may develop due to a different spectrum of allergens at different regions, based on regional differences in the climate, vegetation, humidity and altitude (6). The skin prick test is a safe method; no death has been reported previously, although systemic reactions can occur (7). While allergy tests are important for the evaluation of allergic diseases, they are not sufficient alone to make a diagnosis and should be further supported by an anamnesis of clinical exacerbation or allergen provocation resulting in allergic complaints. Avoiding the allergen is advisable in symptomatic patients with allergies as demonstrated by a positive skin prick test and specific $\operatorname{IgE}$ antibodies in serum. Type and number of environmental pollens vary according to the region, temperature and climate, and the total pollen concentration in the atmosphere can significantly differ based on the vegetation of the geographical region in question, amount of precipitation, and the direction or speed of the wind $(8,9)$. This study was performed to identify the major allergens affecting the patients referring with allergic complaints in Sirnak province and ultimately to contribute to the protection of Sirnak residents from exposure to these allergens.

\section{Material and Methods}

Medical files of 240 patients who referred to Chest Disease policlinics of Sirnak State Hospital between February 2011 and June 2011 with allergic respiratory complaints suggestive of asthma and allergic rhinitis, were retrospectively reviewed and their data were analyzed. Patients' age range was 7-65 years old. Asthma diagnosis was based on detailed medical history, physical exam, patients' symptoms, and overall health and test results. Diagnose of allergic rhinitis was based on patients" symptoms and medical history.
Exclusion criteria: The test was not performed or was postponed for an appropriate time period in the presence of a secondary disease such as an active infection or an active allergic skin disorder, during active treatment with antihistaminic, corticosteroid, anti-inflammatory or immunosuppressive agents that could impair the skin test results, and during pregnancy.

Prick Test: Extracts of 28 common allergens and extracts for positive and negative controls were used for the prick test (Allergopharma produced by Merck KGaA, Darmstadt/Germany). Allergen extracts included household mites Dermatophagoides farinae (D. farinea), and Dermatophagoides pteronyssinus (D. pteronyssinus), grass pollen mixtures (Cynodon dactylon, Fescue, Lolium perenne, Phleum pratense, Poa annua), tree pollen mixtures (Betula pendula, Populus, Pomaderris apetala, Oak Tree, Elm Tree, Ash Tree, Redwood, Willow, common beech, Maple, Juniper, Elderberry, Pine), herbpollen mixture (Absinthe, Pigweed, Parietaria Judaica), cockroach, Aspergillus fumigatus and a mixture of grain allergens (Oak, Barley, Wheat, Rye). Allergen extracts were administered epicutaneously by using separate prick-test applicators. Evaluations were performed after waiting for 20 minutes. Histamine hydrochloride was used as positive control and isotonic was used as negative control. Validity criteria for the test were considered as $>3 \mathrm{~mm}$ positive control and $<$ $3 \mathrm{~mm}$ negative control. Skin reaction against an allergen associated with an induration diameter of at least $3 \mathrm{~mm}$ was considered as a positive response (10).

Statistical Analysis: SPSS 15.0 Windows package software was used for analysis. Independentsamples t test was used to analyze the differences between mean ages. Gender differences were analyzed by $\chi^{2}$ test. $\mathrm{P}$ values $<0.05$ were considered statistically significant.

\section{Results}

240 patients included into the study, 127 (52.9\%) were male and $113(47.1 \%)$ were female. All patients' age range was 7-65 years old. Mean age of women and men was $35.8 \pm 12.1$ years and 31.7 \pm 13.4 years, respectively. Skin prick test result was positive in $106(44.16 \%)$ of tested individuals. Table 1 showed the distribution and frequency of allergens according to gender.

All tested patients were listed based on age and allergic reactions were found to be most common 
Table 1. Comparison of allergic reactions between genders

\begin{tabular}{lccccc}
\hline & Males (n:127) & $\%$ & Females (n:113) & $\%$ & $\mathrm{p}$ \\
\hline Positivity for any allergen & 70 & 55.1 & 36 & 31.85 & $\mathrm{p}>0.05$ \\
Grass & 29 & 22.8 & 12 & 10.6 & $\mathrm{p}>0.05$ \\
Grains & 19 & 15 & 9 & 7.96 & $\mathrm{p}>0.05$ \\
D. Farinea & 11 & 8.6 & 6 & 5.3 & $\mathrm{p}>0.05$ \\
D. Pteronyssinus & 6 & 4.7 & 5 & 4.4 & $\mathrm{p}>0.05$ \\
Herbs & 5 & 3.9 & 4 & 3.5 & $\mathrm{p}>0.05$ \\
\hline
\end{tabular}

Table 2. Skin prick test results according to age groups

\begin{tabular}{lccc}
\hline $\begin{array}{l}\text { Age } \\
\text { (years) }\end{array}$ & $\begin{array}{c}\text { Individuals } \\
(\mathrm{n})\end{array}$ & $\begin{array}{c}\text { Positive } \\
\text { test }(\mathrm{n})\end{array}$ & $\begin{array}{c}\text { Positive } \\
\text { test } \%\end{array}$ \\
\hline $0-9$ & 39 & 22 & 56.4 \\
$10-19$ & 40 & 30 & 75 \\
$20-29$ & 37 & 23 & 62.1 \\
$30-39$ & 34 & 17 & 50 \\
$40-49$ & 27 & 11 & 40.7 \\
$50-59$ & 30 & 2 & 6.6 \\
$60 \leq$ & 33 & 1 & 3 \\
\hline
\end{tabular}

among individuals aged between 10-19 years (Table 2). Allergen frequency according to diseases (asthma, allergic rhinitis, and coexistence of asthma and allergic rhinitis) was shown in table 3.

Skin prick test results of patients referring with allergic complaints indicated that the majority of reactions were against grass pollens, followed by grain allergens mixture and D. Farinea, respectively.

Table 3. Allergen frequency according to diseases

\begin{tabular}{lcccc}
\hline & Asthma(n) & Allergic Rhinitis(n) & Asthma+ Allergic Rhinitis(n) & Total(n) \\
\hline Grass & 11 & 13 & 17 & 41 \\
Grains & 6 & 9 & 13 & 28 \\
D. Farinea & 3 & 4 & 10 & 17 \\
D. Pteronyssinus & 3 & 3 & 5 & 11 \\
Herbs & 2 & 3 & 4 & 9 \\
\hline
\end{tabular}

\section{Discussion}

Epidemiological studies indicate that allergies are associated with the lifestyle, diet and environmental conditions of the individuals. The prevalence of atopy in developed countries increased by 10 -folds over the last 20 years, which highlights the impact of environmental factors on the development of allergies (11-13). Patient age can be a factor affecting the results of skin prick test. Allergic susceptibility increases with age during childhood and reaches to a plateau during adult ages. In general, susceptibility gradually decreases after the age of 50 or 60 years, and the results of skin prick tests performed on individuals at these ages are reliable (14). In the United States, the incidence of atopy was found to be around $40 \%$ among children, while it varied between 10 to $20 \%$ of the adult population (11). In the present study performed on atopic patients living in Sirnak province, skin prick results indicated that $44.16 \%$ of the study population was positive for at least one allergen. The possible reasons underlying such a difference between the figures may be the variations between allergen spectrums of different regions and the severity of allergies among patients referring to a physician.

Previous studies performed in Turkey reported different rates of allergic reactions in patients with atopy. Among those, Cicek et al. (15) reported allergen positivity in $29.3 \%$, Ceylan et al. (16) in $35 \%$, Karabulut et al. (8) in 56.4\% and Ozturk et al. (17) in $56.7 \%$ of their patients. When we reviewed the test results reported by the studies performed in Eastern and Southeast Turkey, we found that Mirici et al. (18) detected allergies against pollen mixtures (grass and trees) in 70.3\% of the patients in Erzurum; in their study performed in Kayseri, Bayram et al. (19) found that allergies were most commonly against pollens by $69.2 \% \quad(53.3 \%$ against tree pollens, $45.8 \%$ 
against herbs and grass, 24.2\% against grain pollens), followed by household mites by $56.7 \%$; in Sanliurfa, Ceylan et al. (16) reported that $87.5 \%$ of the allergies were against grass pollens, $2.3 \%$ against herb pollens and $2.3 \%$ against tree pollens; and in another study performed in Elazig, Cicek et al. (15) found that $18.1 \%$ of the allergies were against household dust and $13.8 \%$ were against grass pollen. In another province with high humidity at low altitude, Edirne, Edis et al. (6) reported that $39.8 \%$ of the allergies were against household mites, $26 \%$ were against trees and $23.5 \%$ were against grass; while in Antalya, Yalçın et al. (20), susceptibilities were reported against household mites in 51.9\% and against pollen mixture in $42.3 \%$ of the cases.

In Sirnak province, we found that 41 patients $(17.1 \%)$ were susceptible to grass, $28(11.6 \%)$ to grains, $17(7.1 \%)$ to D. Farinea, $11(4.6 \%)$ to D. Pteronyssinus and $9(3.7 \%)$ to herb mixture. Tree pollens are the predominant allergens in Kayseri, while grass pollens are apparently more relevant in Sanliurfa $(16,18,19)$. In provinces with high humidity and at low altitude, such as Edirne, Antalya and Duzce, susceptibility to household mites appear to be more predominant $(6,18)$. Nevertheless, there are regions that represent an exception to such a generalization. For instance, susceptibility to household mites is more pronounced in Sakarya province while susceptibility to grass pollens is more common in Mersin province $(21,22)$. Rather than the plants inseminated by insects, those inseminated by the wind are considered to be responsible for pollen allergies and such plants vary depending on regional characteristics (23). Skin prick tests of patients with allergic complaints in Sirnak province showed that the most common allergic susceptibility was against grass pollens, followed by grain pollens and household mites, respectively. Allergic rhinitis and asthma frequently coexist, and $70 \%$ of asthmatic patients are also accompanied with allergic rhinitis (24). The frequency of skin prick test positivity in these patients varies between $29-78 \%$ in Turkey $(15,24)$. In our study skin prick test positivity was $44.16 \%$, and we think that this difference is due to altitude and environmental factors.

In conclusion, protecting atopic patients from the allergens they are susceptible to is the most significant and easiest mode of therapy. Since the present study provided information on the results of allergen susceptibilities in Sirnak province, we believe that our findings can contribute to the protective treatment of atopic patients living in this region.

\section{References}

1. Harmancı E, Us T, Özdemir N, Akgün Y, Aydınlı A, Mutlu S. Solunum sistemi alerjisini saptamada kullanılan deri testleri ve kemiluminesans tekniği ile bakılan serum spesifik IGE arasındaki ilişki. Solunum 2000; 2(1): 31-35.

2. Platts-Mills TA, Vervloet D, Thomas WR, Aalberse RC, Chapman MD. Indoor allergens and asthma: report of the Third International Workshop. J Allergy Clin Immunol 1997; 100(6): 22-24.

3. Peat JK, Tovey E, Toelle BG, Haby MM, Gray EJ, Mahmic A, et al. House dust mite allergens. A major risk factor for childhood asthma in Australia. Am J Respir Crit Care Med 1996; 153(1): 141-146.

4. Poysa L, Korppi M, Pietikainen M, Remes K, Juntunen-Backman K. Asthma, allergic rhinitis, and atopic eczema in Finnish children anad adolescents. Allergy 1991; 46(3): 161-165.

5. Tariq SM, Matthews SM, Hakim EA, Stevens M, Arshad SH, Hide DW. The prevalence of and risk factors for atopy in early childhood: a whole population birth cohort study. J Allergy Clin Immunol 1998: 101(5); 587-593.

6. Edis EC, Tabakoglu E, Caglar T, Hatipoglu ON, Altıay G. Skin prick test results in patients from thrace region presenting with pulmonary symptoms. Balkan Medikal Journal 2007; 24(1): 12-16.

7. Mungan D. Allerji deri testleri. In: Misırligil Z, editör. Allerjik hastalıklar. 1. Baskı. Ankara: Antıp A.Ş 2004; 88-98.

8. Karabulut H, Karadag AS, Acar B, Demir M, Babademez MA, Karasen RM. The evaluation of skin prick test results in Ankara Kecioren area according to meteorologic and demographic features. KBB Forum 2009; 8(3): 46-54.

9. Pinar NM, Geven F, Tug GN, Ketenoglu O. Correlations between meteorological factors and gramineae pollen concentrations in Ankara atmosphere (2007-2008). Astim Allerji Immunoloji 2004; 3(2): 65-70.

10. Polosa R, Al-Delaimy WK, Russo C, Piccillo G, Sarvà M. Greater risk of incident asthma cases in adults with allergic rhinitis and effect of allergen immunotherapy: a retrospective cohort study. Respir Res 2005; 6(1): 153.

11. Sly RM. Changing prevalence of allergic rhinitis and asthma. Ann Allergy Asthma Immunol 1999; 82(3): 233-248.

12. Nicolaou N, Siddique N, Custovic A. Allergic disease in urban and rural populations: increasing 
prevalence with increasing urbanization. Allergy 2005; 60(11): 1357-1360.

13. Silfeler I, Tanidir IC, Arica V. Risk factors for lower respiratory tract infections in children. Pak J Med Sci 2012; 28(3): 488-491.

14. Song WJ, Lee SM, Kim MH, Kim SH, Kim KW, Cho $\mathrm{SH}$, et al. Histamine and allergen skin reactivity in the elderly population: results from the Korean Longitudinal Study on Health and Aging. Ann Allergy Asthma Immunol 2011; 107(4): 344-352.

15. Cicek D, Kandi B, Bakar S, Ucak H. Elazı̆̆ Yöresinde Allerjik Astma, Allerjik Rinit, Allerjik Konjunktivit, Kronik Ürtiker ve Atopik Dermatitli Olgularda Prick Test Sonuçlarının Değerlendirilmesi. FÜ Sağ Bil Derg 2008; 22(4): 193-196.

16. Ceylan E. Şanlıurfa'da bronş astımlı olguların klinik özellikleri. Solunum 2004; 6(1): 5-13.

17. Öztürk Ö, Tokmak A, Güçlü E, Yıldızbaş Ş, Gültekin E. Düzce'de alerjik rinitli hastalarda prick testi sonuçları. Düzce Tıp Fakültesi Dergisi 2005: 1(1); 11-14.

18. Mirici A, Girgiç M, Tutar Ü, Kaynar H. Erzurum'da astımlı hastalarda atopi sıklığı. Akciğer Arşivi 2001; 2(1): 64-68.
19. Bayram A, Oymak S, Gülmez Ö, Demir R, Büyükoğlan H. Astımda atopi ve alerjik rinit sıklığ1. Erciyes Tip Dergisi 2010; 32(1): 27-34.

20. Yalçın AD, Öncel S, Akcan A, Eravşar K, Polat $\mathrm{HH}$, Terzioğlu E. Antalya'da 16 yaş üstünde allerjik astım, rinit ve konjonktivit prevalans1. Turkiye Klinikleri 2010; 30(3): 888-894.

21. Aydemir Y, Coban H, Gungen AC, Duzenli H, Tasdemir C. Seasonal Evaluation of the Skin Prick Test Results in Sakarya Region.. KocaeliMJ 2015; 4(3): 10-13.

22. Pata YS, Akbas Y, Unal M, Ozcan C, Gorur K, Talas DU. Distribution of allergens among allergic rhinitis patients living in Mersin region. Kulak Burun Bogaz Ihtis Derg 2004; 13(5-6): 112-115.

23. Turgut CŞ, Tezcan D, Uzuner N, Köse S, Karaman Ö. İzmir ili ve çevresinde alerjen duyarlıl1k oranlar1. SSK Tepecik Hast Derg 2003; 13(1): 19-24.

24. Coban H, Aydemir Y. The relationship between allergy and asthma control, quality of life, and emotional status in patients with asthma: a crosssectional study. Allergy, Asthma \& Clinical Immunology 2014; 10(1): 67. 